\title{
Medical Treatment in Endometriosis
}

\author{
Elham Pourmatroud \\ Ahvaz Jundishapur University of Medical Science (AJUMS), \\ Iran
}

\section{Introduction}

Two important targets from medical treatment are: pain control and suppression of disease progress. Most of the time, the effectiveness is temporary and lasted while these drugs have been used, which is expected from the nature of endometriosis disease .Of course, there are some debts about the usefulness of pain relief agents, because $30-50 \%$ of patients feel better with placebo administration.

It must to keep in mind that those common administrated drugs couldn't help to restore the fertility potentials and in fact during their usage pregnancy cannot or should not be happened, regarding to inhibition of ovulation or teratogenic effects; of course by their administration with remission of disease (suppress the growth and activity of previous endometriotic implants) and reducing the chance of new peritoneal seeding, fertility may be preserved better; but at the end for achieving pregnancy other ways should be used.

Medical therapeutic drugs divided in two categories:

a. Non hormonal medical therapy.

b. Hormonal medical therapy.

Non hormonal therapeutic options, mainly work on inflammatory and immunologic aspect of endometriosis and hormonal attempts basically deprived endometriotic implants from their nutritive substance: estrogen.

\section{Non hormonal medical therapy}

\subsection{Non-steroidal anti- inflammatory agents}

With attention to inflammatory nature of endometriosis, for decades non- steroidal antiinflammatory agents (NSAIDs) such as naproxen and ibuprofen have been administrated for pain control, in endometriosis. These drugs have been reduced prostaglandins (PGs) production, the main stimulator factor in peritoneal nerves and decrease the nociceptor input messenger from the peritoneal endometriotic implants into central nervous system. Their gastrointestinal upsets and inhibition of ovulation (Duffy \&Stouffer,2002) against low cost and easy availability, always puts NSAIDs in a challenging situation; rather than, new NSAIDs as a selective cyclooxygenase (COX)-2 inhibitors like celecoxib without any effect on PG pathway, could induce apoptosis in endometriotic implants (Seo etal,2010). However 
the latest Cochrane review doesn't show significant effective role of these drugs in patients with endometriosis (Davis etal, 2007).

\subsection{Cytokines inhibitors}

Research in this field is still in primary stages. In animal experiments, cytokines antagonist agents like recombinant human tumor necrotizing factor alpha (TNF- $\alpha$ ) binding protein could inhibit the progress of endometriotic implants and formation of their adhesion (Barrier etal,2004;D'Hooghe etal,2006). Etanercept (ETA) as a TNF antagonist could decrease the volume of peritoneal fluid and proliferation of lesions in endometriotic rats (Zulfikaroglu etal,2011). In a novel study, has been found that TNF could activate estrogen receptor a (ERa); therefore co-administration of a pure ER antagonist with TNF inhibitor could be a more efficacious therapeutic method than usage of one agent, separately (Gori etal,2011).

\subsection{New anti inflammatores}

In cases with persistent non responsive symptom to NSAIDs, other inflammatores like leukotrienes could be inhibited (Abu etal, 2000). In one new study, leukotriene receptor antagonist has been shown to have a significant effect in reduction of stromal proliferation in endometriotic implants (Ihara etal, 2004).

\subsection{Immuno modulators}

Pentoxiphylline administration in human, like a leukotriene receptor antagonist, had promising results in patients with endometriosis. Although it is famous as a vasodilator agent and increase tissue oxygenation in some disease; but could change the immune cell function by inhibition of cytokine and TNF-a secretion. Although in a Cochran review in year 2009, there were not shown enough evidence to support any differences in pregnancy rate in treated patients in comparison with placebo (Lu etal,2009); but in a new report, Vascular endothelial growth factor (VEGF)-C suggested to be an effective factor for significant reduction in endometriotic implants after Pentoxiphylline administration (Vlahos etal,2010).

Also, other immuno modulators like etanercept (ETA) had promising reductive effect equally to letrozole in early investigation (Ceyhan etal ,2011).

\subsection{Alternative medicine}

In a 16 weeks prospective clinical trial, Chinese herbal medicine ( $\mathrm{CHM})$ decoctions have been disclosed hopeful reduction in patient's symptoms especially with dysmenorrhea complaint rather than placebo (Flower etal, 2011). According to Cochrane review, CHM have been shown equal results in comparison with gestrinone with lesser side effects; beside that, the combination of oral $\mathrm{CMH}$ administration with a $\mathrm{CMH}$ enema appear better clinical outcomes (Flower etal, 2009).

As well, there are some published studies about the effectiveness of acupuncture in abdominal pain and significantly in dysmenorrhea relief (M.Chen etal 2010 ; Rubi-Klein etal,2010). In another clinical trial, abdominal acupuncture causing decrease in CA125 level in endometriotic patients (Xiang etal, 2011). 


\section{Hormonal medical therapy}

\subsection{Oral contraceptive pill (OCP)}

Oral combined contraceptive pills induce atrophy in peritoneal endometriotic implants by initial decidualization effect like a pseudo pregnancy situation; perhaps they could increase the apoptosis in endometriotic implants (Meresman etal, 2000). OCPs are the most prescripted drugs in endometriosis, especially in minimal and mild stages of disease for pain control ; although there is a new report about the effectiveness of OCPs usage in patients with deep endometriotic nodules (advance stage) (Mabrouk etal,2011) , which eliminate the effectiveness of OCPs administration only in early stages of disease. In addition, there is not any differences between various available formulations in pain relief potency and any kind of OCPs which had 30-35 $\mu \mathrm{g}$ of ethinyl estradiol could be used and there is no necessity for high dose (HD) contraceptive administration (with $50 \mu \mathrm{g}$ of ethinyl estradiol) (Davis etal,2007). About the usage methods has been shown that, continues usage had better clinical results rather than cyclic administration (Harada etal,2008). In cases of sever atrophy of endometrium and break through bleeding, supplemental estrogen for 7-10 days could be advised.

\subsection{Progestins}

Progestins at the first stage of administration induce decidualization in endometriotic tissues and at the second phase by proliferation inhibition makes atrophia. Also, progestins make depletion in estrogen receptors and inhibit their activation (Kirkland etal, 1992). Progestins could induce transformation of potent form of estrogens (estradiol) to weaker product (estrone) (Tseng etal, 1981). In recent studies discover that there are two important catalyzer enzymes which metabolize progesterone in endometriotic implants. Aldo-Keto reductase 1C1 and 1C3 (AKR1C1 \& AKR1C3) had significant up-regulation expression in ovarian endometriosis which interfere with inhibitory effects of human progesterone (Hevir etal, 2011). It found that exogenous progestins administration could inhibit their activity (Beranic etal, 2011).Various available progestins could be used: oral, parenteral, intrauterine device and implants. With higher dosage of administrated progestins, another effective role of them could be achieved: inhibition of matrix metalloproteinase (Osteen etal , 2003). Most of the time the clinical response to progestins are like the oral contraceptive pills (Schlaff etal,2006), without significant side effects except breakthrough bleeding which can be managed with short time, low dose estrogen administration. Also, the probably bone loss effect is reversible (Cundy etal,1996). The levonorgestrel releasing intrauterine device (LNGIUS) is a valuable therapeutic option especially for women with deep infiltrative endometriotic implants (Lochat etal,2005).About the pain relief efficacy of progestin subdermal implants (Implanon) evidences are limited than other therapeutic modalities (Yisa etal,2005).

\subsection{Gonadotropin-releasing hormone agonists}

Gonadotropin -releasing hormone $(\mathrm{GnRH})$ agonists are synthetic drugs which are resistant to degeneration in body and are produced by some variation in amino acids consequent in natural GnRH agonists. Their resistance to degeneration makes the pituitary gland into 
down regulation state and after suppression of FSH and LH production, menstruation and ovulation had been stopped and therefore, low estrogenic environment achieved which inhibits the proliferation in endometriotic implants. Beside initial flare effect, pseudo menopausal situation produce minor side effects like hot flashes, vaginal atrophia and dryness, headache and other vasomotor signs and symptoms (Dlugi etal,1990) which could be managed by add-back therapy, but after 6 or more continues cycles of drug administration, bone mineral density is going to be reduced sometimes in an irreversible manner (Taga etal,1996); but there is an interesting report about ten years usage of GnRH agonist with add-back therapy without any bone mineral loss (Bedaiwy etal,2006). Unlike the progestins and danazole, GnRH agonists had not adverse effects on lipid profile (Burry etal,1989).Several kinds of injectable GnRH agonists and nasal spray form are available with equal efficacy (Prentice etal,2000).

\subsection{Gonadotropin-releasing hormone antagonists}

Regarding to initial flare effect of $\mathrm{GnRH}$ agonist administration and probably exacerbation effect on endometriosis and a delay between their administration and real hypo estrogenic state and their intolerable side effects in some patients, GnRH antagonists became an suitable substitute for GnRH agonists. Weekly subcutaneous 3-mg cetrotide (GnRH antagonist) injection had been shown clinical efficacy without pseudo menopausal side effects (Finas etal, 2006; Kupker etal, 2002).There are some published advances in oral GnRH antagonist production: Elagolix (C.Chen et al, 2008). In a double blind study in 55 patients, weekly usage of this drug, results effective suppression of gonadal hormonal production (Struthers etal,2009), which could be a promising development in endometriosis treatments modalities instated of injectable options.

\subsection{Androgens}

Danazol is a derivation from testosterone which effect on endometriosis from several ways. Danazol inhibit some steroidogenic enzymes and elevate free testosterone and reduce estrogen level (Barbieri etal, 1981). Also, danazol inhibit mid cycle LH surge (Tamura etal, 1991) and PG F2a production in ovary (Kogo etal,1992), which both of them result chronic anovulation and decrease the chance of new peritoneal seeding.Danazol with $400-800 \mathrm{mg} /$ daily recommended dosage regress the endometriotic implants (Telimaa etal,1987), but severe side effects prevent such dosage administration for an effective period (6 months) (Miller etal,1998).Oily skin, acne, hirsutism, irreversible voice deepness, variation in lipid profile, vaginal atrophia and hot flash limited it's prescription (Hayashi etal,2001).

\subsection{Aromatase inhibitors}

In opposition to other hormonal therapeutic options which reduce ovarian estrogenic production, aromatase inhibitors act not only locally on endometriotic implants, but also on all of estrogenic producers: ovary, brain, adipose tissues (Attar\&Bulun, 2006). Anastrazole $1 \mathrm{mg}$ or letrozole $2.5 \mathrm{mg}$ daily could be effective in pain relief associated with endometriosis (Nothnick, 2011; Shippen\&West, 2004). Because of stimulatory action of aromatase inhibitors in FSH secretion, in premenopausal women they could cause ovarian cysts; 
therefore they administrate with GnRH agonist or OCPs or progestins. This method could reduce the concern about their disadvantage in prolong usage: bone loss (Ferrero etal ,2009).

\subsection{Prolactin secretion inhibitors}

Suppression of cellular immunity and NK cell activity in endometriotic patients has been well known. Also, in stressful situations inhibition of NK cell had been found (Chrousos etal, 2000). Prolactin and cortisol levels in serum are stress indicators. Of course the mechanism of hyper prolactinemia in response to stress isn't so clear, elevated level of serum prolactin had been found in endometriosis like other stressful conditions (Lima etal, 2006, Wang etal, 2009). Interestingly the mean serum prolactin levels are higher in advance stages in endometriotic patients (Gregoriou etal 1999). Quinagolide as a dopamine receptor 2 agonist by reduction in VEGF receptor (a main factor for angiogenesis) could decrease the size of peritoneal lesions and in some cases could eradicate all of endometriotic implants (Gomez etal, 2011). From another aspect quinagolide, is a valuable option for hyper prolactinemia like other dopamine agonists (bromocriptine or caberguline) (Barlier\&Jaquet,2006); therefore this drug could be effectively administrated in endometriosis.

\section{References}

Abu JI, Konje JC (2000). Leukotrienes in gynecology: the hypothetical value of antileukotriene therapy in dysmenorrhea and endometriosis. Hum Reprod Update, Vol. 6, PP.200-205

Attar E, Bulun S (2006). Aromatase inhibitors: the next generation of therapeutics for endometriosis? Fertil Steril, Vol. 85, PP.1307-18

Barbieri RL, Osathanondh R\& Ryan KJ (1981). Danazol inhibition of steroidogenesis in the human corpus luteum .ObstetGynecol,Vol. 57, P. 722

Barlier A, Jaquet P (2006). Quinagolide a valuable treatment option for hyper prolactinemia. Eur J Endocrinol,Vol.154, No.2, PP.187-95

Barrier BF, Bates WB, Leland MM, et al (2004).Efficacy of anti-tumor necrosis factor therapy in the treatment of spontaneous endometriosis in baboons.FertilSteril, Vol.81, PP.775-79

Bedaiwy MA, Casper RF (2006).Treatment with leuprolide acetate and hormonal add-back for up to 10 years in stage 4 endometriosis patients with chronic pelvic pain.FertilSteril, Vol.86, PP.220-222

BeranicN,Gobec S\&Rizner TL (2011).Progestins as inhibitors of the human 20-Ketosteroid reductase, AKR1C1 and AKR1C3.ChemBiol Interact, Vol.191,No.1-3,PP.227-33

Burry KA, Patton PE\& Illingworth DR (1989). Metabolic changes during medical treatment of endometriosis: nafarelin acetate versus danazol, Am J ObstetGynecol , Vol.160, P.1454

Ceyhan ST, Onguru O, Fidan U, et al (2011).Comparison of aromatase inhibitor (letrozole) and immuno modulators (infliximab and etanercept) on regression of endometriotic implants in a rat model.Eur J ObstetGynecolReprodBiol , Vol.154, No.1, PP.100-4 
Chen C, WU D, Guo Z, et al (2008). Discovery of R-(+)-4-\{2-[5-(2- fluoro-3-methyl-2,6-dioxo3,6-dihdro-2H-pyrimidin-1-yI]-1- phenylethylamino\} butyrate (elgolix), a potent and orally available nonpeptide antagonist of the human gonadotropin releasing hormone receptor. J Med Chem, Vol.51,No.23, PP.7478-85

Chen M, Zhang H, Li J, et al (2010). Clinical observation on acupuncture combined with acupoint sticking therapy for treatment of dysmenorrhea caused by endometriosis. Zhongguo Zhen Jiu,Vol.30,No.9,PP.725-8

Chrousos GP, Elenkov IJ (2000).Interactions of the endocrine and immune systems. In: DeGroot LJ, Jameson JL (Editors), Endocrinology. New York: Academic Press ,PP. 571-586

Cundy T, Farquhar CM, Cornish J, etal (1996). Short-term effects of high dose oral medroxyprogesterone acetate on bone density in premenopausal women. J ClinEndocrinolMetab, Vol.81,P.1014

Davis L, Kennedy SS, Moore J, etal (2007). Modern combined oral contraceptives for pain associated with endometriosis. Cochrane Database Syst Rev.CD001019

D'Hooghe TM, Nugent N, Cuneo S, et al (2006). Recombinant human TNF binding protein (r-hTBP-1) inhibits the development of endometriosis in baboons: a prospective, randomized, placebo- and drug-controlled study. Biology of Reproduction. Vol.74, PP.131-36

Dlugi AM, Miller JD\&Knittle J (1990). Lupron depot (leuprolide acetate for depot suspension) in the treatment of endometriosis: a randomized, placebo-controlled, double-blind study. Lupron Study Group, Fertil Steril .Vol.54,P.419

Duffy DM, Stouffer R .(2002). Follicular administration of a cyclooxygenase inhibitor can prevent oocyte release without alteration of normal luteal function in rhesus monkeys. HUM Reprod.V01.17, PP.2825-31

Ferrero S, Camerini G, Seracchioli R, et al (2009). Letrozole combined with norethisterone acetate compared With norethisterone acetate alone in the treatment of pain symptoms caused by endometriosis. Hum Reprod.Vol.24,PP.3033

Flower A, Liu JP, Chen S, etal (2009). Chinese herbal medicine for endometriosis. Cochrane Database Syst Rev .Vol.8, No.3,CD006568

Flower A, Lewith GT\& Little P (2011).A feasibility study exploring the role of Chinese herbal medicine in the treatment of endometriosis. J Altern Complement Med. Vol.17, No.8,PP.691-9

Finas D, Hornung D, DiedrichK,etal (2006).Cetrolix in the treatment of female infertility and endometriosis. Expert OpinPhamacother . Vol.7, No.15, PP.2155-68

Gomez R, Abad A, Delgado F, et al (2011). Quinagolide on endometriotic lesions in patients with endometriosis associated hyper prolactinemia. FertilSteril, Vol.95,N0.3,PP.88288

Gori I, Pellegrini C, Staedler D, et al ( 2011). Tumor necrosis factor-a activates estrogen signaling pathways in endometrial epithelial cells via estrogen receptor $a$. Mol Cell Endocrinol,Vol.345,No.1-2,PP:27-37

Gregoriou G, Bakas P, Vitoratos N, et al (1999). Evaluation of serum prolactin levels in patients with endometriosis and infertility. Gynecol Obstet Invest , Vol.48, PP.48-51

Harada T, Momoeda M, Taketani Y, etal (2008). Low-dose oral contraceptive pill for dysmenorrhea associated with endometriosis: a placebo-controlled, double-blind, randomized trial,FertilSteril.Vol.90,P.1583 
Hayashi T, Takahashi T, Minami T, et al (2001). Fatal acute hepatic failure induced by danazol in a patient with endometriosis and aplastic anemia. J Gastroenterol. Vol.36,PP. 783-86

Hevir N, Vouk K, Sinkovec J, etal (2011). Aldo-KetoReductases AKR1C1, AkR1C2 and AKR1C3 may enhance progesterone metabolism in ovarian endometriosis. ChemBiol Interact .Vol.191,No.1-3,PP.217-26

Ihara T, Uchiide I\&Sugamata M (2004).Light and electron microscopic evaluation of antileukotriene therapy for experimental rat endometriosis.FertilSteril .Vol.81, suppl.1,PP.819-23

Kirkland JL, Murthy L\&Stancel GM (1992).Progesterone inhibits the estrogen-induced expression of c-fos messenger ribonucleic acid inthe uterus, Endocrinology .Vol.130,P.3223

Kogo H, Takasaki K, Yatabe Y, etal (1992). Inhibitory and stimulatory actions of danazol in rat ovarian and uterine tissues. Eur J Pharmacol, Vol.211, No.1,PP.69-73

Kupker W, Felberbaum RE, Krapp M, etal (2002).Use of GnRH antagonists in the treatment of endometriosis.Reprod Biomed Online, Vol.5,No.1, PP.12-16

Lima A.P, Rosa e Silva A.A.M (2006).Prolactin and cortisol levels in women with endometriosis. Brazilian J of Med BiolRes ,Vol.39, PP.1121-27

Lochat FB, Emembolu JO\&Konje JC (2005).The efficacy, side effects and continuation rates in women with symptomatic endometriosis undergoing treatment with an intrauterine administered progesterone (levonorgestrone) :a 3 -year follow -up. Hum Reprod, Vol.20, PP.789-793

LU D, Song H, Li Y, etal (2009).Pentoxiphylline versus medical therapies for sub fertile women with endometriosis. Cochrane Database Of Systemic Reviews .Issue 3.Art. No:CD007677

Mabrouk M, Frasca C, Geraci E, et al (2011).Combined oral contraceptive therapy in women with posterior deep infiltrating endometriosis. J Minim Invasive Gynecol, Vol.18, No.4,PP.470-4

Meresman GF, Vighi S, Buquet RA, etal (2000). Apoptosis and expression of Bcl-2 and Bax in eutopic endometrium from women with endometriosis. FertilSteril. Vol.74,P.760

Miller JD, Shaw RW, Casper RF, et al (1998). Historical prospective cohort study of the recurrence of pain after discontinuation of treatment with danazol or a gonadotropin-releasing hormone agonist.FertilSteril. Vol.70,P.293

Nothnick WB (2011).The emerging use of aromatase inhibitors for endometriosis treatment.ReprodBiolEnocrinol,Vol.9,P.87

Osteen KG, Igarashi TM\& Bruner-Tran KL (2003). Progesterone action in the human endometrium: induction of a unique tissue environment which limits matrix metalloproteinase (MMP) expression, Front Biosci, Vol.8,P.d78

Prentice A, Deary AJ, Goldbeck-Wood S, etal (2000). Gonadotropin- releasing hormone analogues for pain associated with endometriosis, Cochrane Database Syst Rev .CD000346

Rubi-Klein K, Kucera-Sliutz E, Nissel H, et al (2010). Is acupuncture in addition to conventional medicine effective as pain treatment for endometriosis? A randomized controlled cross-over trial.Eur J ObstetGynecolReprodBiol,Vol.153, No.1,PP.90-3 
Schlaff WD, Carson SA, Luciano A, et al (2006). Subcutaneous injection of depot medroxyprogesterone acetate compared with leuprolide acetate in the treatment of endometriosis -associated pain. Hum Reprod,Vol. 21,PP.248-256

SeoSk, Nam A, Jeon YE, et al (2010).Expression and possible role of non-steroidal antiinflammatory drug-activated gene-1 (NAG-1) in the human endometrium and endometriosis. Hum Reprod,Vol.25, N0.12, PP. 3043-9

Shippen ER, West WJ, Jr (2004).Successful treatment of severe endometriosis in two premenopausal women with an aromatase inhibitor.FertilSteril, Vol.81,P.1395

Struthers RS, Nicholls AJ, Grundy J, et al (2009).Suppression of gonadotropins and estradiol in premenopausal women by oral administration of the nonpeptide gonadotropin releasing hormone antagonist elagolix. J ClinEndocrinolMetab, Vol.94, No.2,PP.54551

Taga M, Minaguchi H (1996). Reduction of bone mineral density by gonadotropin-releasing hormone agonist, nafarelin, is not completely reversible at 6 months after the cessation of administration. Acta Obstet Gynecol Scand, Vol.75,P.162

Tamura K, Okamoto R, Takeo S, etal (1991).Inhibition of the first ovulation and ovarian prostaglandin F2 alpha metabolism by danazol in rats.Eur JPharmacol, Vol.202,No.3,PP.317-22

Telimaa S, Puolakka J, RonnbergL,etal (1987). Placebo controlled Comparison of danazol and high-dose medroxyprogesterone acetate in the treatment of endometriosis, GynecolEndocrinol , Vol.1, P.13

Tseng L, Lui HC (1981). Stimulation of arylsulfotransferase activity by progestins in human endometrium in vitro, J ClinEndocrinolMetab, Vol.53,P.418

Vlahos NF, Grogoriou O, Deliveliotou A, et al (2010).Effect of Pentoxiphylline on vascular endothelial growth factor $\mathrm{c}$ and flk-1 expression on endometrial implants in the rat endometriosis model.FertilSteril,vol.93,No.4,PP.1316-23

Wang H, GorpudoloN\&Behr B (2009). The role of prolactin and endometriosis associated infertility. ObstetGynecolSurv,Vol.64, No.8,PP.542-7

Xiang DF, Sun QZ \&Liang XF (2011). Effect of abdominal acupuncture on pain of pelvic cavity in patients with endometriosis . Zhongguo Zhen Jiu,Vol.31,No.2, PP.113-6

Yisa SB, Okenwa AA \&Husemeyer RP (2005).Treatment of pelvic endometriosis with etonogestrel subdermal implant (Implanon). J FamPlannReprod Health Care ,vol.31,PP.67-70

Zulfikaroglu E, Kilic S, Islimye M, et al (2011).Efficacy of anti-tumor necrosis factor therapy on endometriosis in an experimental rat model.RchGynecolObstet,Vol.283, No.4, PP.799-804 


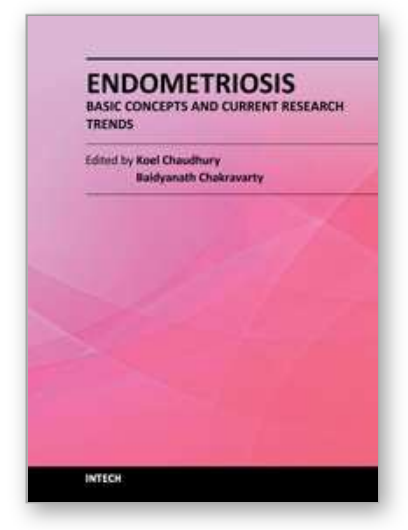

\author{
Endometriosis - Basic Concepts and Current Research Trends \\ Edited by Prof. Koel Chaudhury
}

ISBN 978-953-51-0524-4

Hard cover, 490 pages

Publisher InTech

Published online 09, May, 2012

Published in print edition May, 2012

This book provides an insight into the emerging trends in pathogenesis, diagnosis and management of endometriosis. Key features of the book include overviews of endometriosis; endometrial angiogenesis, stem cells involvement, immunological and hormonal aspects related to the disease pathogenesis; recent research reports on infertility, endometrial receptivity, ovarian cancer and altered gene expression associated with endometriosis; various predictive markers, and imaging modalities including MRI and ultrasound for efficient diagnosis; as well as current non-hormonal and hormonal treatment strategies This book is expected to be a valuable resource for clinicians, scientists and students who would like to have an improved understanding of endometriosis and also appreciate recent research trends associated with this disease.

\title{
How to reference
}

In order to correctly reference this scholarly work, feel free to copy and paste the following:

Elham Pourmatroud (2012). Medical Treatment in Endometriosis, Endometriosis - Basic Concepts and Current Research Trends, Prof. Koel Chaudhury (Ed.), ISBN: 978-953-51-0524-4, InTech, Available from: http://www.intechopen.com/books/endometriosis-basic-concepts-and-current-research-trends/medicaltreatment-in-endometriosis

\section{INTECH}

open science | open minds

\author{
InTech Europe \\ University Campus STeP Ri \\ Slavka Krautzeka 83/A \\ 51000 Rijeka, Croatia \\ Phone: +385 (51) 770447 \\ Fax: +385 (51) 686166 \\ www.intechopen.com
}

\author{
InTech China \\ Unit 405, Office Block, Hotel Equatorial Shanghai \\ No.65, Yan An Road (West), Shanghai, 200040, China \\ 中国上海市延安西路65号上海国际贵都大饭店办公楼405单元 \\ Phone: +86-21-62489820 \\ Fax: +86-21-62489821
}


(C) 2012 The Author(s). Licensee IntechOpen. This is an open access article distributed under the terms of the Creative Commons Attribution 3.0 License, which permits unrestricted use, distribution, and reproduction in any medium, provided the original work is properly cited. 